ESSAY ROUNDTABLE

\title{
THEOLOGY AND LAW DIVORCED AND RECONCILED: AQUINAS, LUTHER, RAWLS, AND US
}

\author{
TIMOTHY P. JACKSON
}

Professor of Christian Ethics, Candler School of Theology, Emory University

KEYWORDS: Love, justice, reason, legal positivism, political agape

What is divinity if it can come

Only in silent shadows and in dreams?

-Wallace Stevens ${ }^{1}$

Let me tell an absurdly brief story about part of the history of theology and law. In this story, I take Thomas Aquinas, Martin Luther, John Rawls, and us as signposts. The tale is overly simple, but it can help situate and challenge us. We are at the end of the long decline into legal positivism; a new era of "political agape" beckons.

\section{THOMAS AQUINAS (I225-I 274)}

The four laws Thomas Aquinas discusses in his Summa Theologica constitute a famous hierarchical unity, characteristic of thirteenth-century scholasticism. ${ }^{2}$ Eternal law is, in effect, the heart and mind of God; divine law (a.k.a. revelation) is a partial transcription or application of eternal law (such as the Ten Commandments in the Hebrew Bible); natural law is the ordered and ordering imprint of the Creator on creation; human law (a.k.a. positive law) is, in turn, a partial transcription or application of natural law (such as the laws on the books of the state of Georgia). For Aquinas, human law has authority and intelligibility only insofar as it coheres with natural law, divine law, and eternal law.

Moreover, according to Aquinas, the first principles of speculative and practical reason are part of natural law and are built into us. Speculative reason is concerned with being/truth, and its first principles of demonstration are noncontradiction and sufficient reason. These principles are per se

I Stevens, "Sunday Morning," in Wallace Stevens: Collected Poetry and Prose (New York: The Library of America, I997), 53. Stevens would replace the transcendent God of traditional Christianity with nature, even as he denies humanity access to reality beyond its own imaginative creations. I find both of these moves unpersuasive, but Stevens asks the right question about divinity. His answer is hyper-romantic, even solipsistic-vide his announcement in Adagia: "The world is myself. Life is myself," ibid., 910-but he was correct to suggest that the theology of the twentieth century faced a crisis. I try in this essay to point beyond that crisis.

2 Aquinas, Summa Theologica, trans. the Fathers of the English Dominican Province (Westminster: Christian Classics, I98I), I-2.90-108. 
nota (self-evident), and the habit of the mind that allows us to comprehend them is intellectus principiorum. Practical reason, in turn, is concerned with the good, and its first principles of action are (formally) "that good is to be done and pursued, evil is to be avoided" and "the precepts of God are to be obeyed," and (materially) self-preservation, preservation of the species-including education of progeny-knowledge of the truth (about God) and life together in society. The habit of the mind that allows us to comprehend these principles is synderesis. Although the image of God has been stained and corrupted to some degree by the Fall, the first principles of speculative and practical reason are universal and inexpungible. ${ }^{3}$

Aquinas sees human nature as created by God with a rational soul that is analogous to the divine mind. The two human abilities that are akin to those of God are our ability to know the truth and our ability to act for an end; and though there is but one intellect, the first of these powers is attributed to speculative reason and the second to practical reason. The two habits of intellectus principiorum and synderesis are habits of the rational soul, and, as Anthony Battaglia has pointed out, they have both theological and philosophical significance. "Theologically, they are an assurance that the human mind conforms to reality in the way in which the Creator intended (an article of faith based on belief in the goodness of God). Philosophically, they function to provide the mind with what Aquinas calls the necessary starting points, first principles, in its knowing the truth and pursuing the good." ${ }^{4}$ Note that the material principles of practical reason can be in tension with the formal principles (for example, self-preservation can be in tension with obedience to God), but there can be no hard contradiction between them, since they are "based on one common foundation"s (ultimately, the will of God).

Aquinas frequently echoes Aristotle and claims that "good is that which all things seek after" or "the good is that at which all actions aim." 6 He further follows Aristotle in saying that to possess a virtue is to possess a habit of acting in accordance with the good. It is important to realize, of course, that he does not mean to deny the possibility of doing something evil. When he says that "the good is that which all things seek," he means that the good is what all things by nature seek; but he was well aware that some people violate their nature and seek evil. Since human beings are rational animals, the human good may be defined as that which all people seek by virtue of their nature as rational animals. But actual virtues are mere potentialities. Again, Aquinas was certainly well aware that some people act irrationally, and some people direct their actions to improper ends, even habitually. Even though the proper object of conjugal love is one's spouse, for example, some people commit adultery. The main point is that, according to Aquinas, practical reason naturally grasps some things as human goods, and the primary precepts of practical reason in turn construe these as things to be done; and practical reason naturally grasps other things as opposed to human goods, and in turn the primary precepts of practical reason construe these as things to be avoided. These points can be summarized with the Aristotelian notion that "we deliberate not about ends but about means."7

Again, Aquinas's account of speculative and practical reason assumes that the Fall of humanity has not totally destroyed our intellectual powers. The first principles of both theory and practice are common to all people and cannot be blotted out, though knowledge of specific truths and performance of particular good actions can be hindered by passion or evil habit or even by what he calls

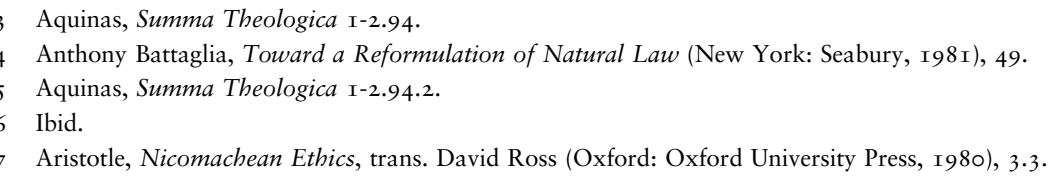


"an evil disposition of nature." ${ }^{\text {The }}$ secondary precepts of natural law can be blotted out-as when theft is not considered wrong among the Germans-but no one loves or performs evil for its own sake. There are limits to the perversity of the human will.

\section{MARTIN LUTHER (I483-I 546)}

Even as his ontology and anthropology is often dualistic - the earthly kingdom governed by Law and the heavenly kingdom governed by Gospel, the "outer man" of the flesh and the "inner man" of the spirit-so there are two Martin Luthers. 9 The Luther of, roughly, I 5 19-1 527 is the revolutionary firebrand who burned the canon law books and emphasized the discontinuity of the world and the church, of Christians and non-Christians. The Luther of the last years of the I 520 s and into the I530s is the more mature reformer, chastened by practicalities, who seeks to retrieve portions of the canon law and who puts the world and the church, law and love, in much more dialectical relation. There is no firm line or single moment of demarcation between Luther-early and Luther-late, but rather the increasing nuance and complexity of certain central ideas.

One such central idea is Luther's initial skepticism concerning the scholastic vision of hierarchical unities. He rejects the idea of priests over laity, reason over emotion, soul over body, sacred over profane, and so on. Unlike Aquinas, for whom faith is "to think with assent" truths about God or contemplating God himself as First Truth, ${ }^{\text {Io }}$ Luther sees faith as an orientation of the whole person in trusting relation with God. Aquinas saw charity as union with God in friendship, but the Beatific Vision itself (that final contemplative union with God in the afterlife) is still a matter of the intellect for him. Luther is far less inclined to follow Aristotle in extoling reason or the intellect as the highest human faculty, claiming instead in "The Freedom of a Christian" ( 1520 ), for example, that humanity and natural reason are "by nature superstitious" and inclined to see the things of God as "foolishness." "I Indeed, with characteristic hyperbole Luther calls reason the Devil's "whore" and "the fountain and headspring of all mischiefs." ${ }^{2}$ To repeat, for Luther faith is not (primarily) cognitive assent to propositions but right relation with God, a matter of throwing yourself on the mercy of God's promise of salvation through grace. Faith is not so much belief that (something is the case) as belief in someone (God).

Related to Luther's mistrust of reason and philosophical reflection in general is his insistence that only scripture is to provide the foundation for Christian faith and life. "Sola Scriptura" is the famous rallying cry. Revelation, or what Aquinas calls divine law, is all Christians can rely on for moral and religious mandates. The idea that we might now read natural laws off of the world or our own nature is naïve. The Fall has profoundly corrupted our speculative and practical

8 Aquinas, Summa Theologica I-2.94.4.

9 I am indebted in this section to John Witte, Jr., Law and Protestantism: The Legal Teachings of the Lutheran Reformation (Cambridge: Cambridge University Press, 2002), especially chapters 3-5. See also Witte, "Law, Politics and Legal Reform," in Oxford Encyclopedia of Martin Luther, ed. Paul Hinlicky and Derek Nelson (New York: Oxford University Press, forthcoming). The chapters of the Oxford Encyclopedia of Martin Luther are also currently available online through the Oxford Research Encyclopedia of Religion, http://religion. oxfordre.com/page/martin-luther.

Io Aquinas, Summa Theologica, 2-2.2, arts. I and 2.

I I Martin Luther, "The Freedom of a Christian," in Martin Luther: Selections from His Writings, ed. John Dillenberger (Garden City: Anchor Books, I96I), 85.

I 2 Martin Luther, "A Commentary on St. Paul's Epistle to the Galatians,” in Dillenberger, Martin Luther, I28. 
reason, and Aristotle is at best irrelevant, at worst a temptation. It is not that Luther overtly denies that there is such a thing as rational natural law; on the contrary, in "Secular Authority" (I 523) he suggests that secular laws enforced by the prince must be based on such natural law. ${ }^{\mathrm{I} 3}$ But natural law is segregated from eternal law and divine law, and the very reason that discerns and codifies natural law is elsewhere seen as highly suspect. Reason and natural law certainly cannot provide the content of Christian ethics. All we have are the two kingdoms, each governed by different principles. The earthly kingdom constituted by non-Christians and governed by secular authority will need to propound human laws that restrain wrongdoing and that are backed by the sword. But true Christians are members of the kingdom of heaven and governed by the gospel of Christ-like love and nonviolence.

In his influential sermon of 1519, Luther specifies two kinds of righteousness, applying to the Christian qua "inner, new man": (I) Alien righteousness equals God's forgiving us from without, independent of any works. We are purely passive to this extrinsic action of mercy healing the rupture of original sin. God simply imputes righteousness to us by treating us as if we were as obedient as his Son who died for us on the cross. This is "the righteousness given in place of the original righteousness lost in Adam." Indeed, this righteousness "accomplishes more" than Adam would have had he not sinned. It is "instilled" in a gradual process, however, finally perfected only "at the end through death." (2) Proper righteousness equals intrinsic disposition to do what the law of God requires. This righteousness completes the first kind and is characterized by love of the neighbor and hatred of self, seeking the other's good and "crucifying the flesh," that is, by following the example of Christ. $^{14}$

The life of proper righteousness sometimes sounds like what Augustine called libertas and what others have traditionally called "sanctification"; moreover, Luther even seems to allow some measure of human cooperation with alien righteousness. In "The Freedom of a Christian," he affirms that a Christian should "increase [his/her] faith until it is made perfect," and that our "one care should be that faith may grow." ${ }_{5} \mathrm{He}$ also notes that, through the second righteousness, the bride responds to the bridegroom "I am yours." ${ }^{16}$ But, in the end, proper righteousness, too, is done to us and for us. In a sense, one has freedom for good works, according to Luther, but not as an independent causal agent and evidently not as a cooperating causal agent. Both kinds of righteousness are pure gifts worked in the elect by God's grace irresistibly. At least in "The Bondage of the Will" ( $\mathrm{I}_{52}$ ), the process is more like a set chain reaction than a genuine response of creature to Creator. To put it another way, the marriage of the bride to the bridegroom seems like a shotgun wedding: the bride's saying "I am yours" could not be otherwise. "We do everything of necessity, and nothing by 'free will'; for the power of 'free will' is nil, and it does no good, nor can do, without grace." ${ }^{77}$ At this stage, Luther simply cannot embrace a picture of virtue as self-perfection acquired even partially through our own efforts.

Thus far, for the early Luther the two kingdoms and nature and grace are quite discontinuous. Near the start of "Secular Authority" ( 1523 ), for instance, we read that "all the children of Adam" are divided into two separate classes: "the kingdom of God" ("true believers in Christ") and "the

I3 Martin Luther, "Secular Authority: To What Extent It Should Be Obeyed," in Dillenberger, Martin Luther, 400-2.

I4 Martin Luther, "Two Kinds of Righteousness," in Dillenberger, Martin Luther, 88-89.

I 5 Luther, "The Freedom of a Christian," 75, 79.

I6 Luther, "Two Kinds of Righteousness," 89.

I7 Martin Luther, "The Bondage of the Will," in Dillenberger, Martin Luther, 188. 
kingdom of the world" (everybody else). ${ }^{\mathrm{I}}$ As Luther starts talking about "self vs. others" and "inner vs. outer," however, he actually begins to put the Christian in both kingdoms simultaneously. A Christian can employ violence to defend other Christians, just not him- or herself, and the imperative to "turn the other cheek" bears on psychic disposition rather than bodily action. In works from the I530s, such as "Commentary on Galatians," the position is pushed further toward paradox. A Christian's being simul justus et peccator implies that he or she wears two hats at once and is governed by the law of love inwardly but the law of the sword outwardly.

In his "Commentary on Galatians" ( I $_{53}$ I), Luther tellingly describes a double use of the law: first, the civil use of the law serves to restrain sin and punish transgressions, "to bridle the wicked," as Luther puts it, ${ }^{19}$ for the sake of keeping the public peace and so that the Gospel might be preached without turmoil. This use, like the second, is ordained by God but does not make people righteous. Indeed, it shows that people are unrighteous: only the unrighteous would need such restraint. The theological use of the law-the so-called "proper" or "principal" use of the lawaccuses Christians and reveals their sin. Standing before the demands of the law (for example, that one love God with all one's heart, mind, and strength), the Christian is convicted of his or her sins, seeing how inadequate one is. Being shown your unrighteousness in this way undermines pride in your own merit and throws you back inwardly on the mercy of God. Luther even goes so far as to say (following Paul) that the theological use of the law is "to increase transgressions." 20 This means simply that confrontation with the commands of God makes you acutely aware of your sins and need for grace, where previously perhaps you were blissfully ignorant of such things. As Richard Hays has pointed out, some reformers point to a third use of the law, a positive set of moral guidelines for Christians. This use is still muted in Luther, I believe, but it is striking that he now speaks much more positively of "reason" and "natural law" as relevant for Christians.

This is the crucial nuancing to which I referred above. We no longer have a simple dichotomy between Law and Gospel, Christians and non-Christians, grace and nature (including free will), and the like, but rather their dialectical interaction. This vision is actually closer to the modern political problematic of personal and social fragmentation and what, arguably, keeps Luther's "two kingdoms" from being just Saint Augustine's "two cities" all over again in German. The rub for the story I am telling, however, is that Lutheran Pietism and Anabaptist sectarianism largely ignored the later Luther's complexity and affirmed a stark either/or between church and world and sacred and profane. ${ }^{2 \mathrm{I}}$ Hence the stage was set for the later John Rawls.

\section{JOHN RAWLS (I92I-2002)}

If Lutheran Pietism effectively lets go of eternal and divine law for the worldly kingdom and renders natural law problematic even in the secular domain, accenting divine law for Christians and human law for non-Christians, ${ }^{22}$ the later John Rawls lets go of everything but human law for everybody,

I 8 Luther, "Secular Authority," 368.

I9 Luther, "A Commentary on St. Paul's Epistle to the Galatians," I 39.

20 Ibid., I40.

2I I owe clarity on this point to John Witte, in conversation.

22 Luther's condemnation of the German Peasants' War of I 524-I 525 amounted to a preferring of human law to natural law, de facto rule over de jure (that is, moral) right, at least for the fractious lower classes. Luther judged the peasants in revolt "faithless" "blasphemers" worthy of death at the hands of princes, thus he betrayed his own (later) best self. See Martin Luther, “Against the Robbing and Murdering Hordes of Peasants,” trans. Charles 
at least for political purposes. The Rawls of Political Liberalism completes "the sectarian project" but from a secular point of view, detaching law from metaphysical hierarchies, faith from universal reason, and love from justice. ${ }^{23}$ (I almost wrote "the Protestant project," but I do not want to offend the Calvinists.) Rawls radicalizes the Jeffersonian understanding of the "wall of separation" between church and state and makes it apply to academy and state as well. For Rawls, human law is "constructed" ${ }^{24}$ on a pragmatic or contractual basis, independently of both religion and philosophy. Human law is not governed by or expressive of any ontological realities - neither the divine will nor human nature-since claims about such things cannot garner agreement even among reasonable people. We must limit the political and legal sphere to a "public reason" that relies on an "overlapping consensus" about "principles of justice" rather than on "comprehensive doctrines" claiming to capture the true, the good, and the beautiful. ${ }^{25}$

We treat fellow citizens as "free and equal persons," ${ }^{26}$ but the crucial question is why? At times, it seems that shared moral and rational powers put all human beings on a political par, as in Kant. ${ }^{27}$ But ultimately such a substantive axiological and anthropological claim is ruled out by "the duty of civility" to prescind from controversial comprehensive doctrines. ${ }^{28}$ In the end, the later Rawls has his contractors endorse freedom and equality, not because this is demanded by human sanctity or dignity, but rather because this is the dominant metaphor of democratic societies. The language of "freedom and equality" is cogent because it allows for public cooperation in a stable society, not because it is an accurate description of human persons, God's commands, or anything else objective.

The early Luther, Jefferson, and the later Rawls would have us internalize or privatize our most profound conceptions of truth and love. For Rawls, in particular, our political motives and selfimages are grounded in a minimal sense of justice and a thin conception of the good, not veracity or charity. Believers may not vote their full consciences in public affairs, thus is divinity consigned to Wallace Stevens's "silent shadows" and "dreams." The persons choosing principles from behind the "veil of ignorance" affirm the "difference principle":

The social and economic inequalities attached to offices and positions are to be adjusted so that, whatever the level of those inequalities, whether great or small, they are to be to the greatest benefit of the least advantaged members of society. ${ }^{29}$

But this affirmation is not based on obedience to God or concern for those who are least well-off, but rather on fear that the choosers themselves might get the short end of the stick. Rawls is clear that he does not mean his thought experiment to reflect the whole of our moral life or moral deliberation, but it still subverts political motives. Rawls insists that his justice as fairness is a moral

M. Jacobs, rev. Robert C. Schultz, in Luther, Selected Writings of Martin Luther I523-1526, ed. Theodore G. Tappert (Philadelphia: Fortress Press, 1967), 345-55.

23 The early Rawls of A Theory of Justice (Cambridge: The Belknap Press of Harvard University Press, 197I) bases political-legal conclusions on ontological and anthropological premises, especially on a Kantian conception of human agency. In his later writings, Rawls insists that public deliberation repudiates this metaphysical dimension.

24 Rawls, Political Liberalism (New York: Columbia University Press, 1996), especially Lecture 3, "Political Constructivism."

25 Ibid., especially Lecture 4, "The Idea of an Overlapping Consensus."

26 Ibid., I9.

27 See, for instance, ibid.

28 Ibid., 216-20.

29 Ibid., 6-7. 
conception, ${ }^{3 \circ}$ but I have argued elsewhere that it amounts to a largely amoral prudence. ${ }^{3 \mathrm{I}}$ Prudence has its place, but it is insufficient for a good society. Such a society requires sympathy for and solidarity with human needs and potentials, not merely self-interest or respect for autonomous choices. For Jews and Christians, the widow, the orphan, and the vulnerable stranger have a claim on us even if we never risk falling into these categories ourselves. Compare the Good Samaritan.

\section{NOW US}

We stand at a crossroad. Thanks to the work of Hal Berman, Paul Ramsey, Amartya Sen, Martha Nussbaum, John Witte, and others, we are now in a position to see the failure of "the sectarian project," insofar as this has led, if unwittingly, to legal positivism. Luther's two kingdoms (in their discontinuous form), Jefferson's wall of separation, and Rawls's public reason are not sufficient for virtuous community, because they are both too minimalist and profoundly divisive. Away with all dualistic language of "two kingdoms" or "us the elect church vs. them the pagan state" or "private perfection vs. political liberalism," for these are invidious and self-serving metaphors. They invite either false pride ("We are God's favorites") or false humility ("Our public discourse is metaphysically neutral”). If Luther, Jefferson, and Rawls cannot make the pragmatic severing of substantive faith and human law work, nobody can.

We must once again open law to the transcendent, cross-fertilizing jurisprudence with theology. There is no neutral or infallible language on the basis of which society can be grounded and governed, and we never have and never will live together based on reward, punishment, and contract alone. We all live by the kindness of strangers, and shared human needs and potentials are even more socially salient than rational agency. Individuals get to be rational agents only because they have first been graciously nurtured by others (and the Holy Other.) It is not necessary or possible to return to thirteenth century scholasticism, and Aquinas is too intellectualist, I believe, in associating the image of God with reason and rational appetite. Some human lives do not possess these capacities, so I have proposed that we identify the imago Dei with the need or ability to give or receive love. ${ }^{2}$ (If God is agapic love, as I John 4:8 avers, then the image of God must refer essentially to such love.) In any case, a just society requires prophetic voices like Amos and Hosea, Martin Luther King, Jr. and Cornel West, attending to the weak and vulnerable, and emphasizing forgiveness and reconciliation, on the one hand, and the avoidance of or resistance to oppression, on the other.

I hasten to add that this is not a brief for theocracy, forced conversion, or intrusive paternalism. I am merely calling on religious believers to speak their minds and vote their consciences in all arenas of life. To borrow from Hays, I am asking them to tell their stories in public, not merely in private, and to bring them imaginatively to bear on everything from the death penalty to same-sex marriage to war and peace. We may well aim at and hope for consensus, but the prophetic does not wait for this. As Brooks Holifield makes plain, American history is replete with unjust and unloving majorities in both church and state; nineteenth century abolitionists, for instance, could not appeal to some uncontroversial jus gentium or public reason to inveigh against slavery. ${ }^{3}$ The claim to

\footnotetext{
30 Ibid., II.

3 I See Timothy P. Jackson, Political Agape: Christian Love and Liberal Democracy (Grand Rapids: William B. Eerdmans, 20I5), chapters 3 and 4 .

32 See ibid., chapter 2.

33 Brooks Holifield, Theology in America: Christian Thought from the Age of the Puritans to the Civil War (New Haven: Yale University Press, 2003), 494-504.
} 
have escaped all ideology is itself a dangerous form of ideology, as the majority opinion in Roe v. Wade makes clear. 34

I am pointing out, then, the priority of love over justice, and the need to return to a wiser balance of the anti-establishment and free exercise clauses of the US Constitution. Antiestablishment never (should have) meant divorcing "religious" values - such as love of neighbor, the sanctity of life, or even faith in God-from political thought and practice. It requires, instead, that the state not found or endorse a church, or privilege believers over nonbelievers as such. Free exercise, in turn, does not prescribe dogmatism or creedal tests for voting rights, much less equating a nation state with the kingdom come. It entails, rather, that short of force or fraud anything goes in democratic debate. Let a thousand flowers bloom; let theists and atheists, Jews and Christians, Hindus and Buddhists, Social Darwinists and Sufis use whatever justifying reasons they can to persuade others.

I second Ellen Ott Marshall's powerful call for epistemic humility, 35 but this does not entail timidity or relativism. Pace Rawls, I have no problem with a Supreme Court Justice or US Senator explicitly voting against the death penalty or elective abortion, say, because he or she thinks it contrary to God's will. Pari passu, I have no in-principle objection to an atheist voting in favor of the death penalty or elective abortion because he or she thinks it is implied by social utility or the will to power. I judge the atheist profoundly mistaken, and I would try to convince my fellow citizens to outvote him or her, but that is not to claim that atheism is to be muzzled a priori. To affirm the legal legitimacy of both religious and nonreligious voices is simply part of freedom of conscience-such freedom itself being, historically, a religiously inspired right, not an Enlightenment apostasy. ${ }^{6}$ Our denying religious freedom would be evil, and so would God's doing so. Prophetic liberalism, in contrast, is true pluralism and the heart of political agape.

34 Writing for the majority, Harry Blackmun claims, "We need not resolve the difficult question of when life begins. When those trained in the respective disciplines of medicine, philosophy, and theology are unable to arrive at any consensus, the judiciary, at this point in the development of man's knowledge, is not in a position to speculate as to the answer." See The Ethics of Abortion: Pro-life vs. Pro-choice, ed. Robert M. Baird and Stuart E. Rosenbaum (Amherst, NY: Prometheus Books, 200I), chapter 7, 68. But then Justice Blackmun and his like-minded colleagues effectively decide exactly this question: the conceptus and pre-viable fetus is not a human life for legal purposes. Such judicial fiat masquerading as metaphysical neutrality threatens civil conversation and democratic governance.

35 Ellen Ott Marshall, “Theological Humility in the World of Law," Journal of Law and Religion 32, no. I (2017) (this issue).

36 See Brian Tierney, The Idea of Natural Rights (Atlanta: Scholars Press, 1997). 